\title{
ADAPTATION OF MURBEI PLANT OF CULTURES IN VITRO OF PEAT SOIL
}

\author{
FARADILLA, SULFIANTO ALIAS, AND ARINI RAJAB
}

\author{
State Agricultural Polytechnic of Samarinda, East Kalimanan, Indonesia
}

\begin{abstract}
Silk Sarong Samarinda is a sarong typical samarinda made using imported silk thread from China. Quality mulberry plants are needed to support the cultivation of silkworms (sericulture). Quality mulberry plants are obtained by in vitro propagation techniques. The success of in vitro culture needs to be supported also by the growth medium suitable for acclimatization stage and plantlet growth. As the medium grows peat has several advantages that are light, water-binding power and high air, porous and can create a good environment for the development of plant roots. Acclimatization by using peat media done in glass house. This research uses Completely Randomized Design (RAL) method with five kinds of growing media combined with manure, compost and charcoal husk and without fertilization as control. Peat soil media successfully used for the growth of mulberry acclimation. Of the five growing media attempted, the best growth of mulberry plants is on peatgrowing medium: manure: charcoal husk (1:1:1) until 12 weeks after planting (MST) the addition of the number of shoots, the addition of the number of leaves as well as to the growth of plant height where at that height mulberry plants ready to be planted in the field.
\end{abstract}

Keywords: in vitro, mulberry, peat soil

\section{INTRODUCTION}

Sarong weaving Samarinda is a typical sarong of Samarinda city. This sarong is made from imported silk spun silk raw material from China. The raw materials are still obtained from outside the city. Nationally, silk threads are still imported. The development of sericulture (silkworm cultivation) is needed to support Samarinda and national industry. The success of nature's natural suturing business is largely determined by the supply of mulberry leaves (Morus sp.) as silkworm feed (Bombyx mori L) in good quantity and quality (Attia et al., 2004). The quality and quantity of mulberry leaves on the growth and health of caterpillars is $38.2 \%$ so it is very important to determine the quality and quantity of coco and silk produced (Banerjee, 1998).

Plant breeding with tissue culture biotechnology can produce prime seed clones. With these technologies the development of mulberry seedlings can accelerate growth compared to conventional mulberry seedlings

Correspondence Author: Faradilla. State Agricultural Polytechnic of Samarinda.

Email: faradilla911@yahoo.co.id

Journal of Wetlands Environmental Management

Vol 6, No 1 (2018) 54-59

http://dx.doi.org/10.20527/jwem.v6i1.108 and can be guaranteed quality, quantity and continuity. Clones or cultivars produced from such technical engineering are expected to have shorter production cycles than conventional mulberry. The success of tissue culture technology does not stop until the laboratory stage, but must also be supported with the growing media appropriate for the acclimatization stage and growth of seedlings. With the availability of suitable growing media, the provision of seeds can be available in large quantities and can support the development of the seed procurement industry (Gunawan, 1995).

Tissue culture is a method of isolating parts of plants such as protoplasm, cells, a group of tissue cells and organs and growing them in aseptic conditions and these parts can multiply themselves and become a complete plant beregerasi. Acclimatization stage is the final stage in tissue culture. A tissue culture is said to succeed if at this stage of acclimatization plants can be moved to the field (Yusnita, 2004)

Acclimatization is the process of adjusting the environmental shift from the hetetrof conditions to the autotrophic environment on plant plantlets obtained through in vitro techniques. The factors that influence the 
growth of planlet during the phase of akimatisasi are planting medium, light intensity, humidity and room temperature. In addition, Budisantoso (2013) also reported that some of the requirements of acclimatization media include having a high water holding ability, good aeration to facilitate root growth and not easily overgrown with mushrooms.

Peat soil is a type of soil that has a high content of organic material formed from the remains of plants that have not completely decomposed due to environmental conditions of poor nutrients and water saturated. Peatlands have a layer of soil from weathering the remnants of plants, mosses to dead animals that are millions of years old. Peat soils are present in wetlands such as swamps, beaches, brackish water or basins. In general, tanagh peat has nutrients and basic saturation $(\mathrm{KB})$ while its acidity $(\mathrm{pH})$ is high. Indonesia has widespread peatland in Sumatra and Kalimantan, which reaches a thickness of 1-12 $\mathrm{m}$. The characteristics of peat soil is to have a soft, soft, wet and the hard texture is pressed, the water in it will come out. The color is dark brown or reddish brown (Anonymous, 2011).

According to Wahyunto et al. (2011) nurseries conducted on peat soils have a faster growth rate than regular soil, as well as producing stronger and stronger seeds. Utilization of peat soil as agricultural land is quite promising, the origin of processing and proper management. In addition, as a growing medium, peat has several advantages that are light, water-binding power and high air, porous and can create a good environment for the development of plant roots. Mulberry seedlings using growing media. Peat is a decomposing organic substance partly formed in wetlands or the accumulation of vegetation, half-decayed large wood. Over time, this material becomes peat which has the richest organic and carbon content compared to other soil types. Based on this background, the research is done with the aim of knowing the ability of adaptation of peat soil to the growth of mulberry planlet (Morus sp.).

\section{MATERIALS AND METHODS}

The research was carried out in the Greenhouse Agricultural Laboratory of Agricultural Polytechnic of State of Samarinda from May to September 2017. Tools and materials used were autoclave, tweezers, scales, small shovels, polybags, mulberry planted, peat soil, manure, charcoal husk, compost and stationery. This study used experimental method with five treatments and five replications for each treatment. The pattern of cropping treatment is as follows: A. Peatsoil (control), B. Peat soil: Manure: husk charcoal (1:1:1), C. Peat soil: Compost: husk charcoal (1:1:1), D Peat soil: Manure husk : husk charcoal (2:1:1), E. Peat soil: compost: husk charcoal $(2: 1: 1)$. For the working procedure some things needed to be done are preparation of planting media, preparation of mulberry planlet, plantlet on planting media and maintenance. Observation parameters observed were live seed presentation, height of seedlings $(\mathrm{cm})$, number of bud and number of mulberry seedlings. All data were collected at 12 weeks after planting (MST). Then the data analysis was done to increase the height of the seedlings, the increase of shoot number and the increase of the number of seedlings. Data were processed using SPSS 13 software. Data analysis using Completely Randomized Design (RAL) then tested using Duncan test at $\mathrm{p}<0.05$.

\section{RESULTS AND DISCUSSION}

The life-force of mulberry seeds that live on some of the composition of planting medium

Based on research on mullet planlet acclimatization on various mixture of peat soil media (Table 1), the results obtained with percentage of mulberry seedlings that live on some planting media compositions. 
Table 1. Life-force of mulberry seeds that live on some planting media compositions for $12 \mathrm{MST}$

\begin{tabular}{clc}
\hline \multirow{2}{*}{ Number } & \multicolumn{1}{c}{ Treatment } & $\begin{array}{c}\text { Live Percentage } \\
(\%)\end{array}$ \\
\hline 1 & A. Peat soil (control) & 85 \\
2 & B. Peat soil : manure: husk charcoal $(1: 1: 1)$ & 100 \\
3 & C. Peat soil : compost : husk cahrcoal $(1: 1: 1)$ & 100 \\
4 & D. Peat soil : manure : husk charcoal $(2: 1: 1)$ & 100 \\
5 & E. Peat soil : compost: husk charcoal $(2: 1: 1)$ & 100 \\
\hline
\end{tabular}

Table 1 clearly demonstrates that the presentation of mulberry seeds in each treatment reached $100 \%$. This is influenced by the media used which is able to support the success of seeds. As it is known that peat soils can be used as planting medium provided that they are processed and the composition of the appropriate media mixture. Peat soils in general have low nutrients and alkaline saturation levels $(\mathrm{pH})$, whereas the level of acidity is high, so with the combination of manure, compost and charcoal husk is very helpful, where manure is an organic material that is able to provide nutrients for plants so compost is also useful for plant growth such as providing nutrients for plants, improving soil nutrient content, increasing the cation exchange capacity (KPK), increasing the ability of soil to retain water, increasing soil $\mathrm{pH}$, and increasing the availability of micro nutrients (Buckman and Brady, 1992). While charcoal plays a role in water and air circulation in plant growth, soil $\mathrm{pH}$ increases so as to increase the availability of
Phosphorus $(\mathrm{P})$. The addition of husk husk to planting media or including agricultural land, will improve the aeration system (air exchange) in the root zone of the plant (Anonymous, 2011). Chaff charcoal is also beneficial to increase groundwater reserves and increase the exchange rate of Potassium $(\mathrm{K})$ and Magnesium $(\mathrm{Mg})$. It is generally known that charcoal or husk husk also has a high but low content of Silicate (Si) element in the calcium content. The silicate element in chaff bark has not been classified as an essential nutrient but presented in all parts of the plant grown on the ground, and recognized as a functional nutrient.

Growth of plant height, number of shoots and number of mulberry seedlings on some plant media composition

Average Growth of seedlings, number of shoots and number of mulberry seedlings on the treatment of some planting media compositions can be seen in Table 2.

Table 2. Average high seed growth, number of buds and number of mulberry seedlings on some planting media compositions

\begin{tabular}{clccc}
\hline Number & \multicolumn{1}{c}{ Treatment } & $\begin{array}{c}\text { High seed } \\
\text { (cm) }\end{array}$ & $\begin{array}{c}\text { Amount } \\
\text { of shoots }\end{array}$ & $\begin{array}{c}\text { Amount } \\
\text { of leaves }\end{array}$ \\
\hline 1 & A. Peat soil (control) & $14,23^{\mathrm{c}}$ & $2,3^{\mathrm{d}}$ & $4,6^{\mathrm{c}}$ \\
2 & B. Peat soil : manure : husk charcoal $(1: 1: 1)$ & $26,45^{\mathrm{a}}$ & $4,8^{\mathrm{a}}$ & $7,4^{\mathrm{a}}$ \\
3 & C. Peat soil : compost : husk charcoal $(1: 1: 1)$ & $21,74^{\mathrm{a}}$ & $4,3^{\mathrm{ab}}$ & $6,7^{\mathrm{ab}}$ \\
4 & D. Peat soil : manure : husk charcoal $(2: 1: 1)$ & $24,28^{\mathrm{b}}$ & $4,1^{\mathrm{b}}$ & $5,8^{\mathrm{b}}$ \\
5 & E. Peat soil : compost : husk charcoal $(2: 1: 1)$ & $22,79^{\mathrm{ab}}$ & $3,5^{\mathrm{c}}$ & $5,2^{\mathrm{b}}$ \\
\hline
\end{tabular}

*) The above figures followed by the same small letters show no significant difference at the 0.01 DMRT level 
The high increase of mulberry seedlings on some planting mediums

Fingerprint results indicate that mulberry seeds grown on a variety of real different planting media compositions are high against mulberry buds (Table 2). The result of observation on the high growth of mulberry seedlings grown with various composition of peat soil: manure: husk charcoal (1:1:1) showed the highest yield of $26.45 \mathrm{~cm}$, followed by peanut peat media composition treatment: manure: chaff charcoal (2:1:1) with the result that is $24.28 \mathrm{~cm}$ and the lowest response is shown by the control treatment that is $14.23 \mathrm{~cm}$. Differences in the results obtained for treatment with various planting media compositions between the use of manure and compost about 3-7 cm. Similarly, the comparison used by planting media. Whereas for the results of control and control treatment and manure compost the difference is very sharp that is between $7-12 \mathrm{~cm}$. This is thought to be due to the effect of manure, the compost provided. According Yuwono (2005) the provision of organic fertilizer into the soil besides aiming to improve the physical condition of the soil also aims to provide nutrients. Similar results were also found in the previous study in which the use of composted planting media and manure on banana plant acclimatization to control (without fertilizing) was very significant (Enjelinam, 2013). Meanwhile, the composition of planting media of manure: husk charcoal: soil $(1: 1: 1)$ produces the best growth of the best banana plant. The best observation results for 12 weeks of research, seen the formation of high seedlings is closely related to the number of shoots produced. The higher the budlet planlet then the number of shoots produced by the planlet will be less. Nursyamsi (2010) reported that the higher the number of shoots then the shoots are formed the shorter. This is due to the nutrients contained in the media used by many buds so that each shoot only obtain a little nutrient elements compared to the treatment that produces a small amount of shoots. Further Duncan test results showed that mulberry seeds grown on peat soil media composition: manure: charcoal (1:1:1) is significantly different from the treatment of peat soil media composition: manure: chaff charcoal $(2: 1: 1)$ and control, but not significantly different from peat soil media: compost: chaff charcoal (1:1:1) and peat soil media: compost: chaff charcoal (2: 1: 1).

An increase in the number of mulberry seed buds on some planting media compositions

In Table 2, the results of variance indicate that the increase in the number of buds of mulberry seedlings grown on various media compositions is significantly different. This means that the addition of planting media composition has a significant effect on the number of mulberry seed buds during 12 MST. The results showed that the number of mulberry seedlings for 12 MST planted on peat soil media composition: manure: husk charcoal $(1: 1: 1)$ gave the best response and resulted in the highest shoot average of 4.8 buds, while the lowest on the control is 2.3. For the next best response is shown by the treatment of the composition of peat soil media media: compost: chaff charcoal $(1: 1: 1)$. This is contrary to the results indicated by the higher growth of mulberry seeds, whereas the second best response to the peat soil media composition is: manure: chaff charcoal (2:1:1). This means that the compost applied to peat soil (1:1) is a suitable composition for the variation in the number of shoots. Buckman and Brady (1992) stated that compost is an indispensable material for agricultural land in Indonesia, in an effort to improve the chemical, physical and biological properties of the soil so that plant growth is better and production can increase. This is supported by the results of Sittadewi et al. (2007) that the acclimatization of gold teak on peat soil was done with best treatment is the composition of planting media of peat and compost (1:1) on plant height variables, shoot number, root number and number of leaves.

\section{Added number of mulberry seedlings on some planting media composition}

Based on Table 2, the average number of mulberry seedlings grown on various media compositions showed significantly different results. Although in general did not show a 
significant difference. The results showed that peat soil media composition: manure: chaff bark (1:1:1) is the optimum composition in yielding the average number of mulberry seedlings, this can be seen from the average number of leaves produced i.e. 7.4 strands, 6.7 strands, 5.8 strands and 5.2 respectively. It seems that the more comparable peat soils are used, the less number of leaves produced. The least number of leaves produced by the control is 4.6 strands. However, the difference is only slightly that is an average of 1 piece. Treatment of peat soil media composition: manure: chaff charcoal (2:1:1) and composition of peat soil media: compost: chaff charcoal (2:1:1) with control, has approximately the same number of 5 pieces. This is allegedly due to the influence of the combination of crops and plant growth on plant growth. It is evident that in all treatments with a combination of manure and compost and chaff charcoal will not have a different effect for increasing the number of leaves for all treatments. According Supirin (2004) there is a way done to increase the soil organic content that is using manure, compost or green manure. Hanafiah (2004) reported that organic matter physically plays a role in stimulating granulation, decreasing flasticity and cohesion, increasing soil resistance into water so that drainage is not excessive, soil moisture and temperature become stable and can increase the number and activity of soil microorganisms. While the function of charcoal husk is to have air circulation and the ability to hold water high (Anonymous, 2011). It can absorb sunlight well because of black, and has a high enough $\mathrm{pH}$ ranged of 8.5-9.0. Increase the bonding power of soil to water and containing macro and micro nutrients Nitrogen, Phosphor, Potassium, Calcium, Manganese, Iron and Zinc.

\section{CONCLUSION}

Based on the results of research on adaptation of mulberry plant result of in vitro culture with various mixture of peat soil media, it can be concluded that mulberry seed succeeded in acclimatization on peat soil. The best planting media composition is peat soil: manure: husk charcoal (1:1:1).

\section{ACKNOWLEDGEMENT}

Our gratitude goes to the DIKTI Director General of the Ministry of Research, Technology and Higher Education Center for funding this research. Thanks also to the Head of Agricultural Polytechnic Research Institute of Samarinda who has facilitated the course of this study, as well as the Head of the Tissue Culture Laboratories of FMIPA UNMUL for their advice and assistance so that the research went smoothly.

\section{REFERENCES}

Anonymous. 2011. Sustainable peatland management. Soil Research Institute. Ministry Agriculture. Jakarta

Attia OA, Eldessoky S, Ehab E, Hanan F. 2004. Micropropagation of mulberry (Morus alba L.). International Journal of Biotechnology and Research, 4: 15-22

Banerjee SP. 1998. Evaluation of mulberry (Morus sp.) genotypes for propagation parameters. Indian Journal of Sericulture. 37: $133-136$

Budisantoso I. 2013. Acclimatization of plant seedlings resulted from tissue culture. Presented in the framework of tissue culture training students of SMP AL Irsyad Purwokerto.

Buckman, Brady N. 1992. Soil science. Bhatara Aksara Karya. Jakarta

Enjelina E. 2013. Acclimatization of banana plantlets (Moses paradisiaca L.) with appropriate planting medium. State Agricultural Polytechnic of Samarinda. Scientific work

Gunawan LW. 1995. Cultural techniques in vitro horticultural crops. Self-help. Jakarta

Hanafiah. 2005. Fundamentals of soil science. PT. Raja Grafindo. Jakarta 
Nursyamsi. 2010. Technique of tissue culture as an alternative to plant propagation to support land rehabilitation. Exposure of research results. Forest Research Institute. Makassar

Sittadewi Hanggari et al. 2003. Utilization of peat soil for growing media of gold teak seedling (Tectona grandis). Science and Technology Library. Journal of Science and Technology. BPTP. Jakarta

Supirin. 2004. Preservation of soil and water resources. Kanisius. Yogayakarta
Yusnita. 2004. Tissue culture: How to multiply plants efficiently. Agromedia Library. Jakarta

Yuwono. 2005. Composting. Universiatas Gadjah Mada Press. Yogyakarta

Wahyunto, Ritung S, Suparto, Subagio. 2011. Description of the carbon content in Sumetra and Kalimantan. Wetlands Internatinal. Bogor

Zulkarnain. 2009. Plant tissue culture. Solution of plant propagation cultivation. Earth Script. Jakarta 